\title{
TOWARD A UNIFORM CLASSIFICATION OF NURSE PRACTITIONER SCOPE OF PRACTICE LAWS
}

\author{
Benjamin J. McMichael \\ Sara Markowitz \\ Working Paper 28192 \\ http://www.nber.org/papers/w28192 \\ NATIONAL BUREAU OF ECONOMIC RESEARCH \\ 1050 Massachusetts Avenue \\ Cambridge, MA 02138 \\ December 2020, Revised March 2023
}

\begin{abstract}
Alicia Gilbert provided excellent research assistance for this paper. The views expressed herein are those of the authors and do not necessarily reflect the views of the National Bureau of Economic Research.

NBER working papers are circulated for discussion and comment purposes. They have not been peer-reviewed or been subject to the review by the NBER Board of Directors that accompanies official NBER publications.

(C) 2020 by Benjamin J. McMichael and Sara Markowitz. All rights reserved. Short sections of text, not to exceed two paragraphs, may be quoted without explicit permission provided that full credit, including $\odot$ notice, is given to the source.
\end{abstract}


Toward a Uniform Classification of Nurse Practitioner Scope of Practice Laws

Benjamin J. McMichael and Sara Markowitz

NBER Working Paper No. 28192

December 2020, Revised March 2023

JEL No. I1,K0

\begin{abstract}
$\underline{\text { ABSTRACT }}$
Many states' scope of practice laws limit the ability of nurse practitioners to deliver care by requiring physician supervision of their practices and prescribing activities. A robust literature has evolved around examining the role of these scope of practice laws in various contexts, including labor market outcomes, healthcare access, healthcare prices, and the delivery of care for specific diseases. Unfortunately, these studies use different, and sometimes conflicting, measures of scope of practice laws, limiting their comparability and overall usefulness to policymakers and future researchers. We address this salient problem by providing a recommended coding of nurse practitioner scope of practice laws over a 24-year period based on actual statutory and regulatory language. Our classification of scope of practice laws solves an important problem within this growing literature and provides a solid legal foundation for researchers as they continue to investigate the effects of these laws.
\end{abstract}

Benjamin J. McMichael

School of Law

University of Alabama

101 Paul W. Bryant Drive, East

Tuscaloosa, AL 35487

bmcmichael@law.ua.edu

Sara Markowitz

Department of Economics

Emory University

Rich Memorial Building

1602 Fishburne Dr.

Atlanta, GA 30322

and NBER

sara.markowitz@emory.edu 


\title{
Toward a Uniform Classification of Nurse Practitioner Scope of Practice Laws
}

\author{
Benjamin J. McMichael ${ }^{1}$ and Sara Markowitz ${ }^{2}$
}

\begin{abstract}
Many states' scope of practice laws limit the ability of nurse practitioners to deliver care by requiring physician supervision of their practices and prescribing activities. A robust literature has evolved around examining the role of these scope of practice laws in various contexts, including labor market outcomes, healthcare access, healthcare prices, and the delivery of care for specific diseases. Unfortunately, these studies use different, and sometimes conflicting, measures of scope of practice laws, limiting their comparability and overall usefulness to policymakers and future researchers. We address this salient problem by providing a recommended coding of nurse practitioner scope of practice laws over a 24-year period based on actual statutory and regulatory language. Our classification of scope of practice laws solves an important problem within this growing literature and provides a solid legal foundation for researchers as they continue to investigate the effects of these laws.
\end{abstract}

\section{Introduction}

Over a decade after the passage of the Affordable Care Act (ACA), access to healthcare remains an important policy priority at the national and state levels, and the recent COVID-19 pandemic has only reinforced the importance of access to care. One policy option that facilitates access to healthcare providers, and thus access to care, is the greater use of advanced practice registered nurses (APRNs) to care for patients with the full extent of their knowledge and training. APRNs are registered nurses (RNs) with advanced degrees and training in primary and specialty care. APRNs are certified to practice in one of four roles: certified registered nurse anesthetists (CRNAs), certified nurse-midwives (CNMs), clinical nurse specialists (CNSs) and nurse practitioners (NPs) (Adams and Markowitz 2018). These nurses examine patients, provide

\footnotetext{
${ }^{1}$ Corresponding author. University of Alabama School of Law, 101 Paul W. Bryant Drive, East, Tuscaloosa, AL 35487, bmcmichael@law.ua.edu. Alicia Gilbert, Morgan Allred, Steffie Rosene, Emily Fedonczak, and Jackson Colburn provided excellent research assistance for this paper.

${ }^{2}$ Emory University Department of Economics and NBER, 1602 Fishburne Drive, Atlanta, GA 30322, sara.markowitz@emory.edu
} 
diagnoses, order tests, provide treatment, and prescribe medications (Adams and Markowitz 2018).

According to the Bureau of Labor Statistics (BLS), in 2019 there were 251,100 employed nurses working as NPs, CRNAs and CNMs (BLS 2019). NPs, the largest group within the APRN category, represent a substantial portion of primary care providers. The 2019 data show 153,980 general practice physicians (including family practitioners, internists, and general practitioners) compared to 200,600 NPs. These nurses play critical roles in the health care system by performing many of the same tasks as primary care physicians and often practice in areas where physicians are in short supply (McMichael 2018). This paper focuses on laws regulating the NP practice, which has implications for access to primary care.

Although they are nationally certified, the practices of NPs are governed by state scope of practice (SOP) laws (McMichael 2018). These laws govern the legal ability of licensed health care professionals to provide medical services. They define providers' roles, articulate oversight requirements (if any), and govern practice and prescriptive authorities. State laws vary along all these dimensions, but foremost is the oversight requirement imposed on individual providers. In many states, NPs must practice under the supervision of or in collaboration with physicians, and these requirements may be imposed through various means, such as practice protocols or other collaborative agreements. Other states allow NPs to practice to the full extent of their training, education, and experience without oversight from physicians. This is termed "full practice authority" (FPA). Over the past few decades, state SOP laws have been evolving from different forms of oversight towards FPA. Currently, 32 states have adopted SOP laws that grant FPA to NPs. 
Given the importance of these laws and that the variation in time and state generates a viable "natural experiment" for policy analysis, it is no surprise that the academic literature evaluating the effects of changing SOP laws is proliferating. Outcomes studied include the quality of care, health care costs and prices, employment, wages, and patient access to care. However, one troubling feature of the literature published to date is that many authors rely on different categorizations of SOP laws. Some authors examine laws that only pertain to practice authority, while others focus only on prescription authority. Still others combine practice and prescription authority. The sources for the laws also vary, with some authors using classifications that are meaningful to nurse advocacy groups but not necessarily appropriate for studying economic or public health outcomes - e.g., regulation of NPs exclusively by a board of nursing. The disparate classifications make interpreting, summarizing, and comparing results across studies rather difficult. We seek to provide some clarity on this issue.

\section{New Contribution}

In this article, we first describe the features of the laws, followed by a description of the different legal categories used by researchers. Next, we present a database of SOP law changes over time that we believe will be useful to academic researchers. Our legal research has been conducted and verified by legal scholars, and we provide citations to current SOP laws to facilitate the continued development of a consistent classification scheme. Our goal here is to provide a resource to the academic community for consistency in SOP law definitions and the timing of adoption for SOP laws. Consistency in these definitions serves two important functions. From the perspective of researchers, consistency will facilitate the comparison of different results and provide greater context for interpreting results more generally. From the 
perspective of policymakers, consistency will provide clearer guidance on which SOP laws are most salient and better insight into which laws should be changed to achieve specific outcomes.

\section{Main Components of SOP laws}

SOP laws are a subset of occupational licensing laws. SOP laws regulate what services members of a profession may provide and the conditions under which they may provide those services. With respect to NPs, not all SOP laws are equally relevant to the economic and public health outcomes that are the focus of most academic and policy-related work. For example, the ability to sign disabled person placards and death certificates falls within the ambit of SOP laws. But the ability to sign such documents is only relevant in limited situations. The two most important — and two most studied — aspects of NP practice governed by SOP laws are physician oversight requirements and prescriptive authority.

\section{Physician Oversight Requirements}

At their most basic level, physician oversight requirements come in two categories: (1) some amount of physician involvement in an NP's practice is required and (2) an NP may practice independently of any physician involvement (McMichael 2020b). Within the first category, states differ in how they require physician involvement in NPs' practices. States may require physician "supervision" of NP practices or they may require that NPs "collaborate" with physicians as a condition of treating patients. While the details of a "collaboration" system generally differ from the details of a "supervision" system, neither system permits an NP to provide healthcare without physician involvement (McMichael, Spetz, and Buerhaus 2019).

Collaboration and supervision often come with legislated administrative responsibilities including chart review, chart certification, and on-site supervision requirements (Markowitz and 
Adams 2018). The specific nature of these requirements may be relevant for individual providers, ${ }^{3}$ but the existence of some or all of these legally mandated responsibilities as a means to require supervision is relevant for economic and public health outcomes in general. The legal requirement of maintaining a relationship with a physician — even if the specifics of the relationship are not particularly arduous—necessarily tethers NPs to physicians and undermines NPs' ability to compete in markets for healthcare services. Accordingly, whether physician involvement is legally mandated as "collaboration" or "supervision" matters relatively little: both forms of involvement have the same legal effect (McMichael 2021).

\section{Prescriptive Authority}

Laws governing prescriptive authority determine what medications NPs may prescribe to patients. Prescription drugs are classified into two main groups of controlled and non-controlled substances. Under the Controlled Substances Act, drugs may be placed on one of five schedules depending on their potential for abuse and accepted medical uses (21 U.S.C. §812).

Classifying NP SOP laws pertaining to prescriptive authority presents a different set of challenges than classifying physician oversight requirements. These challenges stem from differences in how medications themselves are regulated. One option is to classify NP prescriptive authority as including all medications other than Schedule I controlled substances (which are illegal for all providers to prescribe) or not. This option, however, faces several problems. First, certain drugs — such as buprenorphine and clozapine - require all providers to obtain additional certifications to prescribe them (Spetz et al. 2019). Second, some states restrict NPs from prescribing very specific medications, such as weight loss drugs (see Ala. Admin. Code 540-X-17-.03). Third, many states have their own version of the federal Controlled

\footnotetext{
${ }^{3}$ It is relevant to note that though, there is no systematic evidence suggesting that providers actually comply with these requirements.
} 
Substances Act, and states need not perfectly duplicate the federal scheduling process (Gupta et al. 2020).

Given these issues, simply classifying NPs as being allowed to prescribe all nonschedule-I drugs may or may not yield an accurate classification. A clearer approach is to consider what NPs may prescribe and the supervision requirements for that prescribing in the context of the research question under consideration. Defining NP prescriptive authority in this way avoids the problem that laws not directly related to SOP may impact the ability of NP to prescribe certain medications. This approach is also consistent with the goals of research that seeks to evaluate the impact of NP-specific restrictions on outcomes related to NP provided care.

\section{Literature Review}

Table A1 in Appendix A lists twenty-two studies from the economics, legal, and public health literatures that evaluate the effects of changing state SOP laws for NPs on a variety of related outcomes. Table A1 does not contain an exhaustive list, rather it reports recent highquality studies that utilize difference-in-difference methodologies to draw conclusions. The studies covered use either state-based panel data sets or individual-level datasets that span multiple years. The focus of Table A1 is how each study classifies the SOP laws.

The different coding schemes used in this literature can be summarized as follows: (1) Practice authority only, (2) Prescription authority only, (3) Controlled substances allowed, (4) Practice authority and prescription authority included in models separately, and (5) Practice authority and prescription authority considered jointly. Of the studies in the list, 4 studies examine either only practice authority in the models, or include practice and prescription authority separately. Six studies include models that examine prescription authority only. The 
remaining studies examine whether a state has granted FPA or authorizes some level of practice less than FPA. This FPA-or-not distinction is the most relevant for the current policy debate regarding the movement to FPA, as the American Association of Nurse Practitioners (AANP) and other organizations have recognized (AANP 2022). However, the trend toward FPA is fairly recent and may not provide enough variation for studies using older data (when relatively few states had moved to FPA). In addition, using the category of not-FPA results in the loss of information within those states that have not granted FPA.

Although it may be relevant to some studies, we do not present a finer level of detail than FPA for several reasons. First, the volume of legal material pertaining to NPs, physicians, and the healthcare system is quite large. Parsing the many different minor SOP laws is not feasible and is beyond the scope of this paper. Second, the current policy debate heavily focuses on FPA to the exclusion of other, minor considerations. This focus is not surprising, as the passage of FPA renders many other minute questions moot. For example, whether a state imposes chart review requirements or limits NP prescriptions to a formulary become irrelevant once FPA has been passed. Third, the relevance of minor SOP laws depends heavily on the specific context in which individual research occurs. Without knowing this context in advance, it would be impossible for us to determine which NP SOP laws to include. Accordingly, we provide the general legal framework of FPA and encourage future researchers to consider whether additional details are relevant for the specific outcomes and time periods they wish to examine. For example, if a researcher is interested in the link between NP SOP laws and outcomes in intensive care units, SOP laws that speak to whether NPs must be, can be, or may not be admitted to medical staffs may be relevant. The decision of whether to include information beyond the FPA information we provide will need to be made by individual researchers. 


\section{Classifying Scope of Practice Laws}

When classifying SOP laws, many researchers rely on the Nurse Practitioner Annual Legislative Update (NPALU) as the source for the SOP laws. This source publishes annual state-by-state summaries of SOP laws pertaining to practice, reimbursement, and prescription (Phillips 2022). While the NPALU offers a long history of changes to SOP laws - the first version was published in 1989 - it is not aimed at researchers. The publication offers insights for practicing NPs and for those engaged in political activities to change SOP laws. Using this publication in research presents salient problems. The enactment dates given in the publication may not necessarily coincide with the dates that certain laws become effective. The NPALU has addressed this problem in recent editions by including effective dates, but accurate effective dates are not available in earlier editions. It also does not appear to track all sources of law for all states. The annual updates sometimes refer to changes in rules and regulations - in addition to statutes - but not every regulatory change is captured by the annual updates. Our goal is not to criticize this source - it offers valuable information that appears to be quite useful to its primary audiences. We only mean to highlight some potential problems with using the annual updates as the sole source of SOP law changes for the purpose of academic research into the effects of the laws on various outcomes.

Indeed, having independently classified state laws ourselves, we are sympathetic to the difficulties of accurately classifying SOP laws over 51 jurisdictions and multiple decades. To begin to fill the need for a consistent legal classification scheme based on the review of statutes, board of nursing regulations, board of medicine regulations, regulations issued by other state agencies (e.g., boards of public health and departments of health), and court cases, we have compiled a new categorization of state SOP laws. Our categorization meets the need for a 
consistent classification scheme that is based on primary legal sources and that aligns with the current policy discussion, i.e., FPA.

In classifying NP SOP laws, we relied on three legal databases-Westlaw, Lexis, and HeinOnline. These databases are aimed at attorneys and are usually not available to the public or to researchers who lack an affiliation with a school of law. The databases offer several key advantages over the legal sources that many prior classification schemes have relied upon. First, because many sources rely on the publicly available bills passed by the state legislature (session laws), ${ }^{4}$ they often do not have access to accurate effective dates. Some research has attempted to address this issue by simply lagging available dates by one or more years (see Park, Han and Pittman 2020), but doing so does not address the problem of inconsistent effective dates because these will vary from state to state and law to law. By relying on direct access to states' annotated statutory and administrative codes, we avoid these issues. Second, the legal databases we examine contain sophisticated links between state statutes and regulations that better enable us to track small changes in these laws over time. For example, though a statute may instruct a state administrative agency to promulgate a new regulation by a certain date, the administrative agency may fail to do so. Westlaw, Lexis, and HeinOnline allow us to see the actual date a new regulation was promulgated and track other small changes over time.

Using these legal databases, we followed a multi-step approach to categorize individual state SOP laws. We first identified the relevant time frame for classification. We began our classification period in 1998 because, prior to 1998, Medicare did not directly reimburse NPs for

\footnotetext{
${ }^{4}$ For example, the most recent NPALU links directly to publicly available bills and not the actual state code that lawyers, courts, and agencies would rely upon. While these publicly available bills are, in fact, statutes, we rely on annotated state codes instead of bills as passed by legislatures. Bills may undergo small changes prior to being incorporated into the official state code, and the citations we provide are the ones used by attorneys and others involved with the legal system.
} 
their services. Instead, Medicare paid them only for services provided incident to physician services, and many private insurers maintained similar restrictions. Thus, NPs were effectively tethered to physicians under federal law even if state law granted them autonomy. Following the passage of the Balanced Budget Act of 1997, Medicare (and many private insurers) began directly reimbursing NPs (Frakes and Evans 2006). Our classification ends in 2022.

Having identified the relevant time frame, we next identified all relevant state statutes and regulations currently in effect. Several law students then conducted historical research to determine exactly when each relevant statute or regulation became effective. Once they determined the earliest effective date, they then conducted a new search to find any laws in place prior to the relevant effective date. Iterating this process over all states for the time period $1998-$ 2022 allowed us to gather comprehensive information on NP SOP laws. The students were supervised by one of the authors, who is a licensed attorney. Having multiple supervised law students read through individual state statutory and regulatory codes was important because the relevant statutes and regulations sometimes move from one part of a state code to another for various reasons. By carefully tracking these changes, the law students were able to identify the effective dates of different laws with a high degree of accuracy — higher than relying on lay interpretations of publicly available information.

Once the students had identified and coded all the relevant statutes and regulations between 1998 and 2022, a different set of law students reviewed their work and resolved any inconsistencies with additional research. After the second set of law students had completed their tasks, each author independently reviewed their work and conducted additional research to resolve remaining issues. This process, which involved multiple checks by the law student researchers and the authors resulted in our final classification system. 
Table 1 presents our classification of the SOP laws pertaining to NPs from 1998 to 2022. The second column in Table 1 lists the month and year a state first granted FPA to NPs. This is the primary piece of information for researchers to utilize. States are classified as granting NPs FPA if they do not legally mandate any form of supervision by or collaboration with physicians as a condition of NPs practicing and they do not restrict the prescriptive authority of NPs. If a state requires either supervision or collaboration, it is classified as restricting the practices of NPs. Similarly, if a state does not grant NPs prescriptive authority without requiring physician supervision, it is not classified as granting FPA. If a state has allowed NPs to practice with FPA since before 1998, it is classified as always allowing FPA. If a state has never granted NPs FPA between 1998 and 2022, Table 1 states that directly. For those states that have changed their laws since 1998 to grant FPA, Table 1 reports the month and year that FPA became effective based on the relevant statute or regulation.

The third column in Table 1 notes whether a state has allowed NPs to practice without physician oversight under the condition that they do not prescribe. Six states have granted this type of practice independence at some point in time. The fourth column pertains to prescription of controlled substances. This column indicates the states that grant NPs the authority to prescribe controlled substances along with information on whether the controlled substance authority requires physician oversight. We do not provide information on the top level of schedule allowed (II vs III) since, as stated above, there are many nuances to drug scheduling and many states have different rules for some specific Schedule II drugs. The last few columns of the Table include the current statutory and regulatory citations, and notes about state laws that researchers working on specific questions may find useful. 
Table 1 focuses on NPs since they are the largest group (76 percent) of APRNs (BLS 2018). While some types of occupational licensing laws apply to all four types of APRNs - NPs, CNMs, CNSs, and CRNAs - this is not generally true of laws conferring independent practice authority and full prescriptive authority (McMichael 2020a, McMichael 2020b). We recommend that any researcher focusing on CNMs, CNSs, or CRNAs conduct the legal research relevant to the nurses and outcomes under consideration. We note, however, that CNMs are often treated the same or similarly as NPs, whereas CNSs and CRNAs are often treated quite differently.

Table 1 does not specifically include information on whether NPs must sign collaborative practice agreements, supervision agreements, or protocols as a condition of practicing. Legally, these are different mechanisms by which states require physician involvement in NP practices, and all amount to requiring physician oversight of NPs. Some states impose collaborative practice agreements as the specific mechanism of supervision while others do not (choosing an alternative mechanism instead). More generally, practice agreements in various forms all tie NPs to physicians. It is this tying that is of most concern to researchers, rather than the specific mechanism through which the tying occurs. Using our coding system without information and details on collaborative practice agreements will not undermine the conclusions researchers can draw about FPA. However, researchers focusing on questions in certain contexts (such as the administrative burden of specific supervision requirements or the degree of physician involvement in the day-to-day activities of NPs) may want to consider the nature of the collaborative practice agreements required by the states of interest as well as other specific supervision requirements, e.g., chart review requirements. The citations in Table 1 offer a good starting point for those interested in more detail on collaborative practice agreements, as states 
often include those specific requirements close to the general supervision requirements in their statutory and regulatory codes.

In general, the SOP-law classification reported in Table 1 represents the best available information for academic researchers on which states maintained specific SOP laws in the first two decades of this century. We provide current statutory and regulatory citations to SOP laws in Table 1 so that these citations can be used as the basis for both validating and updating the coding of SOP laws. A comparison of the laws and dates presented in Table 1 with those used in prior work and from other sources will reveal a number of differences. These may involve differences stemming from the date of passage, the law's effective date, and the date that rules are promulgated. Other differences involve assumptions about the types or schedules of drugs allowed and consideration of requirements for transition to practice.

\section{Recommendations for Researchers and Implications for Policymakers}

As researchers continue to investigate the role of SOP laws in the provision of healthcare and the labor markets for healthcare providers, several recommendations may facilitate the generation of accurate empirical results that are both policy-relevant and comparable across studies. Our first major recommendation for researchers focused on NPs is to consider using the legal classification scheme outlined above and shown in Table 1. Using the practice authority and prescriptive authority classifications jointly, researchers will be able to examine the primary policy lever that is currently under discussion.

Our second major recommendation concerns how the classification scheme described above is deployed. For most outcomes, researchers will likely want to consider a variable that identifies states with FPA (a state grants NPs independence and full prescriptive authority). For 
example, when focusing on labor market outcomes, a joint variable for full practice authority is likely to be most appropriate since labor market decisions are often based on all characteristics of the job, rather than one aspect such as prescription authority (see Markowitz and Adams 2022 and Luo et al. 2021). When focused on medical care and health outcomes, the choice of examining the joint variable or the separate variables will depend on the outcome under consideration. The one caveat here is that some states have changed practice and prescription authorities simultaneously so including these as separate variables in linear regression models could result in a multicollinearity problem. Researchers should carefully consider which mechanisms of effect they are attempting to isolate and consider which coding scheme is most appropriate for their study setting. The approach we would discourage involves combining prescriptive and practice authority together into one multi-level category with or without other SOP laws. For example, Kuo et al. (2013) combine these two categories with other, highly specific SOP laws and ask a panel of experts to rate each state, placing each state into one of five categories. This type of approach tends to obfuscate which SOP laws drive the relevant results (particularly when many, minor SOP laws are included in addition to practice and prescriptive authority), making comparisons with other studies difficult and potentially confusing policymakers. $^{5}$

Third, and relatedly, as researchers develop their projects, they should determine whether additional legal information is required. For some outcomes, other laws may interact with SOP laws in important ways. Identifying these other laws and how they may or may not modulate the effect of NP SOP laws is an important preliminary step in all studies. In many cases, no other relevant laws will exist. But in some cases — often those of most interest to researchers — other

\footnotetext{
${ }^{5}$ To be clear, this is not the only coding scheme used by Kuo et al. (2013), but we would nevertheless discourage this type of approach.
} 
legal regimes may be relevant. Examples include medical liability laws, laws pertaining to reimbursement, and SOP laws for other practitioners. Understanding these other regimes is important both for designing a study correctly (e.g., controlling for other relevant factors) and for interpreting the results of the study.

Fourth, we recommend that researchers adopt a more consistent terminology. For various reasons, different ways to describe essentially the same law have emerged, and there are often good editorial reasons to do so. We hope to encourage the development of consistency so that studies can more easily be compared to one another. We recommend the term "full practice authority" be used to describe SOP that does not legally mandate any form of supervision by or collaboration with physicians as a condition of NP practice, including prescription authority. We also recommend that researchers be clear when describing independence in one aspect of practice or prescription but not both.

Our fifth recommendation concerns SOP requirements that are not based in law. An emerging trend in the SOP literature is to examine the effects of hospital- or clinic-imposed requirements on NPs (Pittman et al. 2020). These institutions often have authority to restrict the practices of NPs to a greater extent than state law does. These restrictions are necessarily based on the contracts that exist between NPs and these institutions and should not be treated as interchangeable with statutes and regulations. One important reason for this is that the restrictions will only apply at the relevant institution and would not affect the NPs at other places of practice. Another important reason concerns the interpretation of these restrictions, which will necessarily occur under contract law. Courts may use similar legal tools when interpreting contracts, statutes, and regulations, but contract interpretation is nonetheless different than statutory or regulatory interpretation. Thus, a requirement imposed by statute may have a 
different impact than the same requirement imposed by a healthcare institution via contract. We do not mean to suggest that institution-specific SOP requirements are unimportant; we only mean to caution against treating these requirements the same as SOP laws.

Finally, we note that the recommendations above have important implications for policymakers. By focusing specifically on the definition of FPA laid out here (or the components of FPA), researchers can improve the usefulness of their results to policymakers. The use of our classification scheme will allow policymakers to know exactly which laws are driving any relevant effects estimated by researchers. In contrast to other approaches that rely on indices or minor SOP laws combined with more broadly-reaching SOP laws, our scheme clearly identifies the components of SOP laws that matter most. Additionally, the use of our classification system will enable policymakers and their staff to look up the relevant laws in Table 1, which will smooth the process of potentially amending those laws. If more researchers use our coding system, the comparability across studies will also improve and better allow policymakers to determine the effects of amending NP SOP laws.

\section{Conclusion}

While the coding of legal variables may not attract as much attention among economists and health policy researchers as identification strategies and other econometric questions, ensuring these variables correctly code the laws of interest is key to correctly estimating the effects of those laws. In this paper, we offer a new, consistent coding scheme for NP SOP laws based on statutory and regulatory research. This scheme offers substantive advantages over existing approaches. Each coded variable includes a legal citation that is verifiable to other researchers, policymakers, and attorneys. And the variables are coded at the month level, which may be important for certain health outcomes of interest to researchers. Our coding scheme does, 
however, have some important limitations. It does not, for example, include an exhaustive list of all SOP laws that may be of interest to researchers. And it should not be used for professionals other than NPs. With respect to NPs, however, we hope our new scheme will simplify the legal research necessary to engage in SOP research and facilitate consistent and accurate research in this important area of health policy. 


\section{References}

Adams, E. K., \& Markowitz, S. (2018). Improving efficiency in the health-care system: Removing anticompetitive barriers for advanced practice registered nurses and physician assistants. Policy Proposal, 8: 9-13.

Alexander, D., \& Schnell, M. (2019). Just what the nurse practitioner ordered: Independent prescriptive authority and population mental health. Journal of Health Economics, 66: 145-162.

AANP (2022). Issues at a Glance: Full Practice Authority. https://www.aanp.org/advocacy/advocacyresource/policy-briefs/issues-full-practice-brief.

Bureau of Labor Statistics (BLS) (2019). May 2019 National Occupational Employment and Wage Estimates United States. Bureau of Labor Statistics, U.S. Department of Labor, Washington DC.

https://www.bls.gov/oes/current/oes_nat.htm\#29-0000

DePriest, K., D'Aoust, R., Samuel, L., Commodore-Mensah, Y., Hanson, G., \& Slade, E. P. (2020). Nurse practitioners' workforce outcomes under implementation of full practice authority. Nursing outlook, 68(4), 459-467.

Frakes, M.A., \& Evans, T. (2006) An Overview of Medicare Reimbursement Regulations For Advanced Practice Nurses. Nursing Economics, 24: 59-65.

Grecu, A. M., \& Spector, L. C. (2019). Nurse practitioner's independent prescriptive authority and opioids abuse. Health Economics, 28(10): 1220-1225.

Gupta, S., Nguyen T. D., Freeman, P. R., Simon, K. I. (2020) Competitive Effects of Federal and State Opioid Restrictions: Evidence from the Controlled Substances Laws. NBER Working Paper 27520, https://www.nber.org/papers/w27520.

Institute of Medicine, Committee on Monitoring Access to Personal Health Care Services. (1993). Access to health care in America. Washington, DC: National Academy Press; https://www.ncbi.nlm.nih.gov/books/NBK235882/

Kandrack, R., Barnes, H., \& Martsolf, G. R. (2021). Nurse practitioner scope of practice regulations and nurse practitioner supply. Medical Care Research and Review, 78(3), 208-217.

Kleiner, M. M., Marier, A., Park, K. W., \& Wing, C. (2016). Relaxing occupational licensing requirements: Analyzing wages and prices for a medical service. The Journal of Law and Economics, 59(2): 261-291.

Kuo, Y., Loresto, F. L., Rounds, L. R., Goodwin, J. S. (2013). States With The Least Restrictive Regulations Experienced The Largest Increase In Patients Seen By Nurse Practitioners. Health Affairs, 32(7), 1236-1243.

Kurtzman, E. T., Barnow, B. S., Johnson, J. E., Simmens, S. J., Infeld, D. L., \& Mullan, F. (2017). Does the regulatory environment affect nurse practitioners' patterns of practice or quality of care in health centers?. Health services research, 52: 437-458.

Luo, T., Escalante, C. L., \& Taylor, C. E. (2021). Labor market outcomes of granting full professional independence to nurse practitioners. Journal of Regulatory Economics, 1-33.

Markowitz, S., \& Adams, E. K. (2022). The effects of state scope of practice laws on the labor supply of advanced practice registered nurses. American Journal of Health Economics, 8(1): 65-98.

Markowitz, S., Adams, E. K., Lewitt, M. J., \& Dunlop, A. L. (2017). Competitive effects of scope of practice restrictions: Public health or public harm?. Journal of Health Economics, 55: 201-218.

McMichael, B. J. (2018). Beyond Physicians: The effect of licensing and liability laws on the supply of nurse practitioners and physician assistants. Journal of Empirical Legal Studies, 15(4): 732-771. 
McMichael, B. J., Safriet, B. J., \& Buerhaus, P. I. (2018). The extraregulatory effect of nurse practitioner scope-ofpractice laws on physician malpractice rates. Medical Care Research and Review, 75(3): 312-326.

McMichael, B. J., Spetz, J., \& Buerhaus, P. I. (2019). The Association of Nurse Practitioner Scope-of-Practice Laws With Emergency Department Use. Medical care, 57(5): 362-368.

McMichael, B.J. (2020a). Healthcare Licensing and Liability. Indiana Law Journal, 95(3): 821—881.

McMichael, B. J. (2020b). Occupational licensing and the opioid crisis. UC Davis L. Rev., 54, 887.

Muench, U., Whaley, C., Coffman, J., \& Spetz, J. (2021). Scope-of-practice for nurse practitioners and adherence to medications for chronic illness in primary care. Journal of general internal medicine, 36(2), 478-486.

Park, J., Han, X., \& Pittman, P. (2020). Does expanded state scope of practice for nurse practitioners and physician assistants increase primary care utilization in community health centers?. Journal of the American Association of Nurse Practitioners, 32(6), 447-458.

Perry, J. J. (2012). State-granted practice authority: Do nurse practitioners vote with their feet?. Nursing research and practice, 2012.

Phillips, S. J. (2022). 34 ${ }^{\text {th }}$ Annual APRN Legislative Update: Trends in APRN practice authority during the COVID19 global pandemic. The Nurse Practitioner, 47(1), 21-47.

Pittman, P., Leach, B., Everett, C. Han, X., \& McElroy, D. (2020). NP and PA Privileging in Acute Care Settings: Do Scope of Practice Laws Matter?. Medical Care Research and Review, 77(2) 112-120.

Poghosyan, L., Ghaffari, A., Liu, J., Jin, H., \& Martsolf, G. (2021). State policy change and organizational response: Expansion of nurse practitioner scope of practice regulations in New York State. Nursing Outlook, 69(1), 74-83.

Traczynski, J., \& Udalova, V. (2018). Nurse practitioner independence, health care utilization, and health outcomes. Journal of Health Economics, 58: 90-109.

Shakya, S., \& Plemmons, A. (2020). Does Scope of Practice Affect Mobility of Nurse Practitioners Serving Medicare Beneficiaries?. Journal of Labor Research, 1-14.

Spetz, J., Parente, S.T., Town, R.J., \& Bazarko, D. 2013. "Scope-of-Practice Laws for Nurse Practitioners Limit Cost Savings That Can Be Achieved in Retail Clinics." Health Affairs, 32(11): 1977-84.

Spetz, J., Toretsky C., Chapman, S., Phoenix, B., Tierney, M. (2019). Nurse Practitioner and Physician Assistant Waivers to Prescribe Buprenorphine and State Scope of Practice Restrictions. JAMA, 321(14): 1407-1408.

Stange, K.. 2014. "How Does Provider Supply and Regulation Influence Health Care Markets? Evidence from Nurse Practitioners and Physician Assistants." Journal of Health Economics, 33: 1-27.

Timmons, E.J. 2017. "The Effects of Expanded Nurse Practitioner and Physician Assistant Scope of Practice on the Cost of Medicaid Patient Care." Health Policy, 121 (2): 189-96. 
Table 1: Nurse Practitioner Scope of Practice Laws, 1998-2022 a

\begin{tabular}{|c|c|c|c|c|c|c|}
\hline State & $\begin{array}{c}\text { FPA } \\
\text { Status } \\
\text { 1998-2022 }^{\mathrm{b}}\end{array}$ & $\begin{array}{l}\text { Independence in } \\
\text { Practice if no } R X\end{array}$ & $\begin{array}{l}\text { Controlled Substance } \\
\text { Authority }^{\mathrm{d}}\end{array}$ & $\begin{array}{l}\text { Practice } \\
\text { Citation }\end{array}$ & $\begin{array}{l}\text { Prescription } \\
\text { Citation }\end{array}$ & Notes \\
\hline Alabama & Never & Never & $\begin{array}{l}\text { Aug. 2013-present: } \\
\text { allowed with oversight }\end{array}$ & $\begin{array}{l}\text { Code of Ala. } \S \\
34-21-85 . I d . \S \\
34-21-86 . \\
\end{array}$ & $\begin{array}{l}\text { Code of Ala. } \S \\
34-21-86 .\end{array}$ & \\
\hline Alaska & Always $^{\mathrm{c}}$ & N/A & Always allowed & $\begin{array}{l}\text { Alaska Admin. } \\
\text { Code tit. } 12, \S \\
44.430 . I d . \S \\
44.445 .\end{array}$ & $\begin{array}{l}\text { Alaska Admin. } \\
\text { Code tit. } 12, \S \\
44.440 .\end{array}$ & \\
\hline Arizona & $\begin{array}{l}\text { December } \\
1999\end{array}$ & $\begin{array}{l}\text { Allowed prior to } \\
\text { Dec. } 1999 .\end{array}$ & $\begin{array}{l}\text { 1998-Dec 1999: allowed } \\
\text { with oversight } \\
\text { Dec 1999-present: allowed }\end{array}$ & $\begin{array}{l}\text { Ariz. Rev. Stat. } \S \\
32-1601(22) . I d . \\
\S 32-1651 .\end{array}$ & $\begin{array}{l}\text { Ariz. Rev. Stat. } \S \\
32-1651 .\end{array}$ & $\begin{array}{l}\text { Arizona includes some restrictions on opioid } \\
\text { prescribing. Independence in practice without } \\
\text { prescribing was allowed prior to } 1999 \text { but still } \\
\text { required the establishment of a relationship with a } \\
\text { physician for consultation or referral. }\end{array}$ \\
\hline Arkansas & July 2021 & Not until FPA & $\begin{array}{l}\text { 1998-2021: Allowed with } \\
\text { oversight }\end{array}$ & $\begin{array}{l}\text { Ark. Code Ann. } \\
\S 17-87-314\end{array}$ & $\begin{array}{l}\text { Ark. Code Ann. } \S \\
17-87-310\end{array}$ & \\
\hline California & $\begin{array}{l}\text { Never-See } \\
\text { Note }\end{array}$ & $\begin{array}{l}\text { Not until FPA-See } \\
\text { Note }\end{array}$ & $\begin{array}{l}\text { Allowed with oversight - } \\
\text { See Note }\end{array}$ & $\begin{array}{l}\text { Cal. Bus \& } \\
\text { Prof Code } \S \\
2835.103-04\end{array}$ & $\begin{array}{l}\text { Cal. Bus \& } \\
\text { Prof Code } \S \\
2836.1 .\end{array}$ & $\begin{array}{l}\text { California passed a bill in } 2020 \text { to grant NPs FPA, } \\
\text { but the law does not become effective until } 2023\end{array}$ \\
\hline Colorado & July 2010 & Not until FPA & $\begin{array}{l}\text { 1998-July 2010: allowed } \\
\text { with oversight } \\
\text { July 2010-present: } \\
\text { allowed }\end{array}$ & $\begin{array}{l}\text { Colo. Rev. } \\
\text { Stat. } \S 12-38- \\
111.5 . I d . \S 12- \\
255-112 .\end{array}$ & $\begin{array}{l}\text { Colo. Rev. Stat. } \S \\
12-255-112 .\end{array}$ & \\
\hline Connecticut & July 2014 & Not until FPA & $\begin{array}{l}\text { 1998-July 2014: allowed } \\
\text { with oversight } \\
\text { July 2014-present: } \\
\text { allowed }\end{array}$ & $\begin{array}{l}\text { Conn. Gen. Stat. } \\
\S 20-87 \mathrm{a} .\end{array}$ & $\begin{array}{l}\text { Conn. Gen. Stat. } \S \\
20-87 \text { a. }\end{array}$ & \\
\hline Delaware & $\begin{array}{c}\text { September } \\
2015\end{array}$ & Not until FPA & $\begin{array}{l}\text { 1998-Sept. 2015: allowed } \\
\text { with oversight } \\
\text { Sept. 2015-present: } \\
\text { allowed }\end{array}$ & $\begin{array}{l}\text { Del. Code Ann. } \\
\text { tit. } 24, \S 193 \text {. }\end{array}$ & $\begin{array}{l}\text { Del. Code Ann. } \\
\text { tit. } 24, \S 1935 \text {. }\end{array}$ & \\
\hline
\end{tabular}




\begin{tabular}{|c|c|c|c|c|c|c|}
\hline $\begin{array}{l}\text { District of } \\
\text { Columbia }\end{array}$ & Always $^{c}$ & N/A & Always allowed & $\begin{array}{l}\text { D.C. Code } \S 3- \\
1206.01 \text {. }\end{array}$ & $\begin{array}{l}\text { D.C. Code } \S 3- \\
1206.01 \text {. }\end{array}$ & \\
\hline Florida & July 2020 & Not until FPA & $\begin{array}{l}\text { Jan. 2017-July 2020: } \\
\text { allowed with oversight } \\
\text { July 2020-present: } \\
\text { allowed }\end{array}$ & $\begin{array}{l}\text { Fla. Stat. Ann. } \S \\
464.0123 .\end{array}$ & $\begin{array}{l}\text { Fla. Stat. Ann. } \S \\
464.012 .\end{array}$ & $\begin{array}{l}\text { Only NPs engaged in "primary care practice, } \\
\text { including family medicine, general pediatrics, and } \\
\text { general internal medicine" may practice } \\
\text { independently of physicians. }\end{array}$ \\
\hline Georgia & Never & Never & $\begin{array}{l}\text { July 2006-present: } \\
\text { allowed with oversight }\end{array}$ & $\begin{array}{l}\text { Ga. Code Ann. § } \\
43-34-25 \text {. }\end{array}$ & $\begin{array}{l}\text { Ga. Code Ann. } \S \\
43-34-25 \text {. }\end{array}$ & \\
\hline Hawaii & July 2009 & $\begin{array}{l}\text { Prior to July } 2009 \text {, } \\
\text { independent in } \\
\text { practice if no RX } \\
\text { and document a } \\
\text { collegial working } \\
\text { relationship with } \\
\text { MD. }\end{array}$ & $\begin{array}{l}\text { April 2005-July 2009: } \\
\text { allowed with oversight } \\
\text { July 2009-present: } \\
\text { allowed }\end{array}$ & $\begin{array}{l}\text { Haw. Rev. Stat. } \\
\text { Ann. } \S 457-2.7 . \\
\text { Id. } \S 457-8.6 .\end{array}$ & $\begin{array}{l}\text { Haw. Rev. Stat. } \\
\text { Ann. } \S 457-8.6 \text {. }\end{array}$ & \\
\hline Idaho & July 2004 & Not until FPA & $\begin{array}{l}\text { July 1998-July 2004: } \\
\text { allowed with oversight } \\
\text { July 2004-present: allowed }\end{array}$ & $\begin{array}{l}\text { Idaho Code } \S 54- \\
\text { 1402(1). }\end{array}$ & $\begin{array}{l}\text { Idaho Code } \S 54- \\
\text { 1402(1). }\end{array}$ & \\
\hline Illinois & June 2019 & Not until FPA & $\begin{array}{l}\text { August 1998-2018: } \\
\text { allowed with oversight } \\
\text { June 2019-present allowed }\end{array}$ & $\begin{array}{l}225 \text { Ill. Comp. } \\
\text { Stat. Ann. } 65 / 65- \\
43 \text {. }\end{array}$ & $\begin{array}{l}225 \text { Ill. Comp. } \\
\text { Stat. Ann. } 65 / 65- \\
40 .\end{array}$ & $\begin{array}{l}\text { NPs can only prescribe benzodiazepines and } \\
\text { Schedule II narcotics in "consultation" with a } \\
\text { physician. }\end{array}$ \\
\hline Indiana & $\begin{array}{l}\text { Never-See } \\
\text { Note }\end{array}$ & Never-See Note & Allowed with oversight & $\begin{array}{l}\text { Ind. Code Ann. } \S \\
\text { 25-23-1-19.4. }\end{array}$ & $\begin{array}{l}\text { Ind. Code Ann. § } \\
25-23-1-19.5 .\end{array}$ & $\begin{array}{l}\text { Indiana allows NPs to practice with "all of the } \\
\text { supervisory rights and responsibilities, including } \\
\text { prior authorization, that are available to a licensed } \\
\text { physician or a health service provider in psychology } \\
\text { (HSPP) operating in a community mental health } \\
\text { center" when providing care to Medicaid patients. }\end{array}$ \\
\hline Iowa & Always $^{c}$ & N/A & Always allowed & $\begin{array}{l}\text { Iowa Code } \S \\
152 \mathrm{E} .3 \text {. }\end{array}$ & $\begin{array}{l}\text { Iowa Code } \S \\
147.107 .\end{array}$ & \\
\hline Kansas & $\begin{array}{l}\text { Never-See } \\
\text { Note }\end{array}$ & Never-See Note & $\begin{array}{l}\text { April 2000-present: } \\
\text { Allowed with oversight }\end{array}$ & $\begin{array}{l}\text { Kan. Stat. Ann. § } \\
65-1130 .\end{array}$ & $\begin{array}{l}\text { Kan. Stat. Ann. § } \\
65-1130(d) .\end{array}$ & $\begin{array}{l}\text { Kansas passed a statute in } 2022 \text { granting full practice } \\
\text { authority, but it is not yet effective. }\end{array}$ \\
\hline Kentucky & Never & $\begin{array}{l}\text { Effective July } 15, \\
2014 \text {, can prescribe } \\
\text { non-controlled } \\
\text { drugs }\end{array}$ & $\begin{array}{l}\text { August 2006-present: } \\
\text { Allowed with oversight }\end{array}$ & $\begin{array}{l}\text { Ky. Rev. Stat. } \\
\text { Ann. } \S 314.042 .\end{array}$ & $\begin{array}{l}\text { Ky. Rev. Stat. } \\
\text { Ann. } § \\
314.042(10) .\end{array}$ & \\
\hline
\end{tabular}




\begin{tabular}{|c|c|c|c|c|c|c|}
\hline & & $\begin{array}{l}\text { independently after } \\
4 \text { years of } \\
\text { collaboration with } \\
\text { a physician. }\end{array}$ & & & & \\
\hline Louisiana & Never & Never & $\begin{array}{l}\text { Feb 1998-present: allowed } \\
\text { with oversight. }\end{array}$ & $\begin{array}{l}\text { La. Stat. Ann. § } \\
\text { 37:913. }\end{array}$ & $\begin{array}{l}\text { La. Stat. Ann. § } \\
\text { 37:913(8). }\end{array}$ & \\
\hline Maine & Always $^{c}$ & N/A & Always allowed & $\begin{array}{l}\text { Me. Rev. Stat. } \\
\text { Ann. tit. } 32, \S \\
\text { 2102. Id. } \S 221 ; \\
\text { Me. Code of } \\
\text { Regs. } \\
\S 02.380 .008 ;\end{array}$ & $\begin{array}{l}\text { Me. Rev. Stat. } \\
\text { Ann. tit. 32, § } \\
2210 \text {. }\end{array}$ & \\
\hline Maryland & $\begin{array}{l}\text { October } \\
\text { 2010-See } \\
\text { Note }\end{array}$ & $\begin{array}{l}\text { Not until FPA-See } \\
\text { Note }\end{array}$ & $\begin{array}{l}\text { 1998-Oct 2010: allowed } \\
\text { with oversight } \\
\text { Oct 2010-present: allowed }\end{array}$ & $\begin{array}{l}\text { Md. Code Ann., } \\
\text { Health } \\
\text { Occupations } \S 8 \text { - } \\
302 \text {. }\end{array}$ & $\begin{array}{l}\text { Md. Code Ann., } \\
\text { Health } \\
\text { Occupations } \S 8 \text { - } \\
\text { 512(a)(2). }\end{array}$ & $\begin{array}{l}\text { Prior to Oct } 12010, \text { NPs had collaborative } \\
\text { agreements. As of Oct } 12010 \text {, NPs must file an } \\
\text { attestation form with the state that declares the NP } \\
\text { will collaborate with a named physician and will } \\
\text { adhere the rules governing the scope of practice for } \\
\text { their certification, but the attestation does not require } \\
\text { the physician collaborator's signature and, once } \\
\text { filed, NPs may practice independently. The } \\
\text { requirement for attestation was eliminated Oct } 1 \\
2015 \text {. }\end{array}$ \\
\hline Massachusetts & $\begin{array}{l}\text { January } \\
2021\end{array}$ & Not until FPA & $\begin{array}{l}\text { 1998-2020: allowed with } \\
\text { oversight } \\
\text { Jan 2021-present: allowed }\end{array}$ & $\begin{array}{l}\text { Mass. Ann. Laws } \\
\text { ch. 112, § 80E. } \\
\text { 244 Mass. Code } \\
\text { Regs. } 4.02 .\end{array}$ & $\begin{array}{l}1397 \text { Mass. Code } \\
\text { Regs. } 57(2.10) \text {. }\end{array}$ & \\
\hline Michigan & Never & $\begin{array}{l}\text { Physician } \\
\text { delegation not } \\
\text { required for non- } \\
\text { controlled drugs as } \\
\text { of April } 2017 \\
\end{array}$ & $\begin{array}{l}\text { April 2017-present: } \\
\text { allowed with oversight }\end{array}$ & $\begin{array}{l}\text { Mich. Comp. } \\
\text { Laws Serv. § } \\
\text { 333.17211a. }\end{array}$ & $\begin{array}{l}\text { Mich. Comp. } \\
\text { Laws Serv. § } \\
\text { 333.17211a. }\end{array}$ & $\begin{array}{l}\text { Prescribing controlled substances is a delegated act } \\
\text { of a physician }\end{array}$ \\
\hline Minnesota & $\begin{array}{l}\text { January } \\
2015\end{array}$ & Not until FPA & $\begin{array}{l}\text { 1998-2014: allowed with } \\
\text { oversight } \\
\text { 2015-present: allowed }\end{array}$ & $\begin{array}{l}\text { Minn. Stat. } \\
148.235 .\end{array}$ & $\begin{array}{l}\text { Minn. Stat. § } \\
148.235 .\end{array}$ & \\
\hline Mississippi & Never & Never & $\begin{array}{l}\text { July 2002: allowed with } \\
\text { oversight }\end{array}$ & $\begin{array}{l}\text { Miss. Code Ann. } \\
\S 73-15-20 \text {. }\end{array}$ & $\begin{array}{l}\text { Miss. Code Ann. } \\
\S 73-15-20 .\end{array}$ & \\
\hline Missouri & Never & Never & Allowed with oversight & $\begin{array}{l}\text { Mo. Rev. Stat. § } \\
334.104 .\end{array}$ & $\begin{array}{l}\text { Mo. Ann. Stat. § } \\
\text { 334.104. }\end{array}$ & \\
\hline
\end{tabular}




\begin{tabular}{|c|c|c|c|c|c|c|}
\hline Montana & Always ${ }^{c}$ & N/A & Allowed & $\begin{array}{l}\text { Mont. Code Ann. } \\
\S 37-8-409 .\end{array}$ & $\begin{array}{l}\text { Mont. Admin. R. } \\
24.159 .1461 \text {. }\end{array}$ & \\
\hline Nebraska & $\begin{array}{l}\text { March } \\
2015\end{array}$ & Not until FPA & $\begin{array}{l}\text { 1998-March 2015: allowed } \\
\text { with oversight } \\
\text { March 2015-present: } \\
\text { allowed }\end{array}$ & $\begin{array}{l}\text { Neb. Rev. Stat. } \\
\text { Ann. } \S 38-2315 \text {. }\end{array}$ & $\begin{array}{l}\text { Neb. Rev. Stat. } \\
\text { Ann. § 38-2315. }\end{array}$ & \\
\hline Nevada & July 2013 & Not until FPA & $\begin{array}{l}\text { May 2001-July 2013: } \\
\text { allowed with oversight. } \\
\text { July 2013-present: } \\
\text { allowed }\end{array}$ & $\begin{array}{l}\text { Nev. Rev. Stat. } \\
\text { Ann. } \S 632.237 . \\
\text { Id. } \S 639.1375 . \\
\text { Id. } \S 639.2351 .\end{array}$ & $\begin{array}{l}\text { Nev. Rev. Stat. } \\
\text { Ann. § 639.1375. }\end{array}$ & $\begin{array}{l}\text { Cannot prescribe Schedule II drugs unless } 2 \\
\text { years/ } 2000 \text { hours clinical experience or unless } \\
\text { controlled substance is prescribed pursuant to a } \\
\text { protocol approved by a collaborating physician. }\end{array}$ \\
\hline New Hampshire & Always ${ }^{\mathrm{c}}$ & N/A & Allowed & $\begin{array}{l}\text { N.H. Rev. Stat. } \\
\text { Ann. § 326-B:11. }\end{array}$ & $\begin{array}{l}\text { N.H. Rev. Stat. } \\
\text { Ann. § 326-B:11. }\end{array}$ & \\
\hline New Jersey & Never & Never & $\begin{array}{l}\text { August 2004-present: } \\
\text { allowed with oversight }\end{array}$ & $\begin{array}{l}\text { N.J. Stat. Ann. § } \\
\text { 45:11-49. }\end{array}$ & $\begin{array}{l}\text { N.J. Stat. Ann. § } \\
\text { 45:11-49. }\end{array}$ & \\
\hline New Mexico & Always $^{c}$ & N/A & Allowed & $\begin{array}{l}\text { N.M. Stat. Ann. } \\
\S 61-3-23.2 \text {. }\end{array}$ & $\begin{array}{l}\text { N.M. Stat. Ann. § } \\
61-3-23.2 \text {. }\end{array}$ & \\
\hline New York & $\begin{array}{c}\text { January } \\
2015-\text { See } \\
\text { Note }\end{array}$ & $\begin{array}{l}\text { Not until FPA-See } \\
\text { Note }\end{array}$ & $\begin{array}{l}\text { 1998-2014: allowed with } \\
\text { oversight } \\
\text { Jan. 2015-present: allowed }\end{array}$ & $\begin{array}{l}\text { N.Y. Educ. Law } \\
\S 6902 .\end{array}$ & $\begin{array}{l}2020 \text { N.Y. CLS } \\
\text { Educ Consol. } \\
\text { Laws Adv. Legis. } \\
\text { Serv. § 6902(3). }\end{array}$ & $\begin{array}{l}\text { As of Jan. 2015, NPs need to attest to a collaborative } \\
\text { relationship with a physician, but are otherwise } \\
\text { independent. Local NPs interpret the } 2015 \text { change in } \\
\text { the law as allowing full practice authority } \\
\text { (Poghosyan et al. 2020). New York passed a statute } \\
\text { granting full practice authority in } 2022 \text {. }\end{array}$ \\
\hline North Carolina & Never & Never & Allowed with oversight & $\begin{array}{l}\text { N.C. Gen. Stat. § } \\
90-18.2 \text {. }\end{array}$ & $\begin{array}{l}\text { N.C. Gen. Stat. § } \\
\text { 90-18.2. }\end{array}$ & \\
\hline North Dakota & $\begin{array}{l}\text { October } \\
2011\end{array}$ & Not until FPA & $\begin{array}{l}\text { 1998-Oct 2011: allowed } \\
\text { with oversight } \\
\text { Oct 2011-present: allowed }\end{array}$ & $\begin{array}{l}\text { N.D. Cent. Code } \\
\S 43-12.5-01 .\end{array}$ & $\begin{array}{l}\text { N.D. Admin. } \\
\text { Code } 54-05-03.1- \\
03 .\end{array}$ & \\
\hline Ohio & Never & Never & $\begin{array}{l}\text { Feb. 2002-present: } \\
\text { allowed with oversight }\end{array}$ & $\begin{array}{l}\text { Ohio Rev. Code } \\
\text { Ann. } \$ 4723.43 \text {. }\end{array}$ & $\begin{array}{l}\text { Ohio Rev. Code } \\
\text { Ann. } § 4723.50 \text {. }\end{array}$ & \\
\hline Oklahoma & Never & Never & Allowed with oversight & $\begin{array}{l}\text { Okla. Stat. tit. } \\
59, \S 567.3 \mathrm{a}(6) .\end{array}$ & $\begin{array}{l}\text { Okla. Stat. tit. 59, } \\
\S 567.4 \text { a. }\end{array}$ & \\
\hline Oregon & Always ${ }^{c}$ & N/A & Allowed & $\begin{array}{l}\text { Or. Rev. Stat. } \S \\
678.375(4) \text {. }\end{array}$ & $\begin{array}{l}\text { Or. Rev. Stat. § } \\
678.390 .\end{array}$ & \\
\hline Pennsylvania & Never & Never & $\begin{array}{l}\text { Nov } 2000 \text {-present: allowed } \\
\text { with oversight }\end{array}$ & $\begin{array}{l}\text { 63 Pa. Cons. } \\
\text { Stat. § } 218.2 \text {. } \\
\text { Id. § } 218.3 \text {. }\end{array}$ & $\begin{array}{l}63 \text { Pa. Cons. } \\
\text { Stat. } \S 218.3 .\end{array}$ & \\
\hline
\end{tabular}




\begin{tabular}{|c|c|c|c|c|c|c|}
\hline Rhode Island & June 2013 & Not until FPA & $\begin{array}{l}\text { 1998-Jun 2013: allowed } \\
\text { with oversight } \\
\text { Jun 2013-present: allowed }\end{array}$ & $\begin{array}{l}\text { 216-RICR-40- } \\
05-3\end{array}$ & $\begin{array}{l}\text { R.I. Gen. Laws } \S \\
5-34-49 \text {. }\end{array}$ & $\begin{array}{l}\text { Regulations arguably granting full practice authority } \\
\text { were promulgated in January/February } 2012 \text {. Rhode } \\
\text { Island changed its statute to allow full practice } \\
\text { authority in June } 2013.5 \text { R.I. Gen. Laws } \S 5-34-44 \text {. }\end{array}$ \\
\hline South Carolina & Never & Never & $\begin{array}{l}\text { May 2004-present: allowed } \\
\text { with oversight }\end{array}$ & $\begin{array}{l}\text { S.C. Code Ann. } \\
\S 40-33-34 .\end{array}$ & $\begin{array}{l}\text { S.C. Code Ann. § } \\
40-33-34 .\end{array}$ & \\
\hline South Dakota & July 2017 & Not until FPA & $\begin{array}{l}\text { 1998-July 2017: allowed } \\
\text { with oversight } \\
\text { July 2017-present: allowed }\end{array}$ & $\begin{array}{l}\text { S.D. Codified } \\
\text { Laws } \S 36-9 A- \\
12 .\end{array}$ & $\begin{array}{l}\text { S.D. Codified } \\
\text { Laws } \S 36-9 A-12 \text {. }\end{array}$ & \\
\hline Tennessee & Never & Never & Allowed with oversight & $\begin{array}{l}\text { Tenn. Code Ann. } \\
\S 63-7-123 \text {. }\end{array}$ & $\begin{array}{l}\text { Tenn. Code Ann. } \\
\S 63-7-123 \text {. }\end{array}$ & \\
\hline Texas & Never & Never & $\begin{array}{l}\text { May 2003-present: } \\
\text { allowed with oversight }\end{array}$ & $\begin{array}{l}\text { Tex. Occ. Code } \\
\text { Ann. § } 157.0512 .\end{array}$ & $\begin{array}{l}\text { Tex. Occ. Code } \\
\text { Ann. § } 157.0512 .\end{array}$ & \\
\hline Utah & May 2016 & See Note & $\begin{array}{l}\text { 1998-May 2016: allowed } \\
\text { with oversight } \\
\text { May 2016-present: allowed }\end{array}$ & $\begin{array}{l}\text { Utah Code Ann. } \\
\S 58-31 \mathrm{~d}-102 .\end{array}$ & $\begin{array}{l}\text { Utah Code Ann. } \S \\
\text { 58-17d-102(23); } \\
\text { Utah Code Ann. § } \\
\text { 58-31b-803. }\end{array}$ & $\begin{array}{l}\text { Prior to May 2016, independent in practice and } \\
\text { prescription only for Schedules IV and V. Schedules } \\
\text { II and III required a consultation and referral (C\&R) } \\
\text { plan with a consulting physician. After May 2016, } \\
\text { Schedule II requires a C\&R plan for inexperienced } \\
\text { APRNs. }\end{array}$ \\
\hline Vermont & June 2011 & Not until FPA & $\begin{array}{l}\text { 1998-June 2011: allowed } \\
\text { with oversight } \\
\text { June 2011-present: allowed }\end{array}$ & $\begin{array}{l}\text { Vt. Stat. Ann. tit. } \\
26, \S \S 1611 \text {, } \\
1613 .\end{array}$ & $\begin{array}{l}04-030-170 \mathrm{Vt} . \\
\text { Code R. } \S 8.5 .\end{array}$ & \\
\hline Virginia & April 2018 & Not until FPA & $\begin{array}{l}\text { Allowed Schedules II } \\
\text { through VI on and after } \\
\text { July 1,2006 with } \\
\text { oversight. } \\
\text { April 2018-present: } \\
\text { allowed }\end{array}$ & $\begin{array}{l}\text { Va. Code Ann. } \S \\
54.1-2957 . I d . \S \\
54.1-2957.01 .\end{array}$ & $\begin{array}{l}\text { Va. Code Ann. } \S \\
54.1-2957.01 .\end{array}$ & \\
\hline Washington & $\begin{array}{c}\text { Jan } 2006- \\
\text { See notes }\end{array}$ & See Note & $\begin{array}{l}\text { See note: Prior to August } \\
19,2001, \text { Schedule V and } \\
\text { non-controlled drugs only. } \\
\text { Effective August } 19,2001 \text {, } \\
\text { Schedules II-IV allowed. }\end{array}$ & $\begin{array}{l}\text { Wash. Rev. Code } \\
\text { Ann. } \S \\
18.79 .050 .\end{array}$ & $\begin{array}{l}\text { Wash. Rev. Code } \\
\text { Ann. } \S 18.79 .050 .\end{array}$ & $\begin{array}{l}\text { Prior to } 8 / 19 / 01 \text {, APRNs had independent PA and RX, } \\
\text { but RX was limited to Schedule } \mathrm{V} \text { and non-controlled } \\
\text { drugs. From } 8 / 19 / 01 \text { to } 1 / 21 / 06 \text { a joint practice } \\
\text { agreement was required for controlled substance } \\
\text { prescriptions. The JPA is a written agreement that } \\
\text { describes how collaboration will occur between the } \\
\text { physician and the ARNP (i.e. when and how the } \\
\text { ARNP will consult regarding the Rx of controlled }\end{array}$ \\
\hline
\end{tabular}




\begin{tabular}{|c|c|c|c|c|c|c|}
\hline & & & & & & $\begin{array}{l}\text { substances). The JPA was eliminated when FPA } \\
\text { became effective } 1 / 21 / 2006 \text {. }\end{array}$ \\
\hline West Virginia & June 2016 & Not until FPA & $\begin{array}{l}\text { 1998-June 2016: allowed } \\
\text { with oversight } \\
\text { June 2016-present: allowed }\end{array}$ & $\begin{array}{l}\text { W. Va. Code } \\
\text { Ann. § 9-4B-1. } \\
\text { Id. § 30-7-15b. }\end{array}$ & $\begin{array}{l}\text { W. Va. Code Ann. } \\
\S 30-7-15 b \text {. }\end{array}$ & \\
\hline Wisconsin & Never & Never & Allowed with oversight & $\begin{array}{l}\text { Wis. Stat. § } \\
\text { 961.395. Id. § } \\
441.16 .\end{array}$ & $\begin{array}{l}\text { Wis. Stat. } \S \\
961.395(2020) \text {; } \\
\text { Wis. Stat. } \S \\
441.16 .\end{array}$ & \\
\hline Wyoming & Always $^{\mathrm{c}}$ & $\mathrm{N} / \mathrm{A}$ & Always allowed & $\begin{array}{l}\text { Wyo. Stat. Ann. } \\
\S 33-21-302 .\end{array}$ & $\begin{array}{l}\text { Wyo. Stat. Ann. } \\
\text { 33-21- } \\
120 \text { (a)(i)(A). }\end{array}$ & \\
\hline
\end{tabular}

${ }^{a}$ This table excludes laws and executive orders that were enacted as part of the Covid-19 public health emergency.

${ }^{\mathrm{b}}$ Some states require a transition to practice period that requires an NP to be supervised for some amount of time before being granted full practice authority.

${ }^{c}$ State has always allowed full practice authority since at least 1998.

${ }^{\mathrm{d}}$ State allows prescription of controlled substances on Schedules V through III or II. The start date of 1998 in this column indicates the law extended at least as far back as 1998. The initial effective date of these laws is not reported. 
APPENDIX A: LITERATURE REVIEW

Table A1: Literature on Scope of Practice for Nurse Practitioners

\begin{tabular}{|c|c|c|c|c|c|}
\hline Study & $\begin{array}{l}\text { SOP Law Separate- } \\
\text { Practice Authority } \\
\text { (PA) }\end{array}$ & $\begin{array}{l}\text { SOP Law Separate- } \\
\text { Prescription Authority } \\
\text { (RX) }\end{array}$ & $\begin{array}{l}\text { SOP Laws for } \\
\text { PA and RX both } \\
\text { included }\end{array}$ & $\begin{array}{l}\text { SOP Data Source } \\
\text { and Years Included }\end{array}$ & Main findings \\
\hline $\begin{array}{l}\text { Alexander and Schnell } \\
\text { (2019) }\end{array}$ & & Independent & & $\begin{array}{l}\text { NPALU, state nursing } \\
\text { boards, state statutes } \\
\text { 1990-2014 }\end{array}$ & $\begin{array}{l}\text { No effect on suicides. } \\
\text { Independent RX } \\
\text { associated with fewer } \\
\text { mental health related } \\
\text { deaths, fewer days in } \\
\text { poor mental health. } \\
\text { Mixed results for } \\
\text { prescription rates. }\end{array}$ \\
\hline DePriest et al. (2020) & & & FPA & $\begin{array}{l}\text { NPALU based on } \\
\text { AANP classification, } \\
2010-2018\end{array}$ & $\begin{array}{l}\text { FPA positively } \\
\text { associated with: NP } \\
\text { self-employment; } \\
\text { residing in health } \\
\text { professional shortage } \\
\text { area. } \\
\text { FPA not associated } \\
\text { with NP earnings }\end{array}$ \\
\hline $\begin{array}{l}\text { Grecu and Spector } \\
(2019)\end{array}$ & & $\begin{array}{l}\text { Independent for } \\
\text { Schedule II CS }\end{array}$ & & $\begin{array}{l}\text { State statutes, 2003- } \\
2015\end{array}$ & $\begin{array}{l}\text { No effect on opioid } \\
\text { treatment admissions } \\
\text { nor mortality unless } \\
\text { combined with a } \\
\text { prescription drug } \\
\text { monitoring program. }\end{array}$ \\
\hline Kandrack et al. (2019) & & & FPA & NPALU, 2010-2017 & $\begin{array}{l}\text { No effect on nurse } \\
\text { supply }\end{array}$ \\
\hline
\end{tabular}




\begin{tabular}{|l|l|l|l|l|l|}
\hline Kleiner et al. (2016) & & $\begin{array}{l}\text { Mutually exclusive } \\
\text { categories: } \\
\text { Independent } \\
\text { - Supervised/delegated } \\
\text { (CS only under } \\
\text { supervision) } \\
\text { - Limited (no CS, } \\
\text { legend under } \\
\text { supervision }\end{array}$ & $\begin{array}{l}\text { Independent in PA } \\
\text { Independent in RX }\end{array}$ & NPALU, 1999-2010 & $\begin{array}{l}\text { Independent PA: } \\
\text { increased NP earnings, } \\
\text { no effects on hours }\end{array}$ \\
& & $\begin{array}{l}\text { Independent RX: no } \\
\text { effect on NP earnings, } \\
\text { increased hours, lower } \\
\text { price for well-child } \\
\text { visits, no effect on } \\
\text { infant mortality; no } \\
\text { effect on physician } \\
\text { malpractice insurance }\end{array}$ \\
\hline Kurtzman et al. (2017) & $\begin{array}{l}\text { Independent (no } \\
\text { restrictions + sole } \\
\text { authority by BON) }\end{array}$ & Independent & $\begin{array}{l}\text { No differences in } \\
\text { quality of care } \\
\text { associated with either } \\
\text { independence in PA or } \\
\text { independence in RX }\end{array}$ \\
\hline Luo et al. (2021) & & $\begin{array}{l}\text { FPA associated with } \\
\text { more work hours and } \\
\text { higher probability of } \\
\text { working in an } \\
\text { ambulatory care } \\
\text { setting. No effect on } \\
\text { wages. }\end{array}$ \\
\hline $\begin{array}{l}\text { Markowitz and Adams } \\
\text { (2022) }\end{array}$ & & $\begin{array}{l}\text { FPA } \\
\text { higher likelihood of } \\
\text { self-employment and } \\
\text { more hours worked. } \\
\text { No effect of laws on } \\
\text { probability of nursing } \\
\text { employment, part-time } \\
\text { work, working } \\
\text { multiple jobs, and }\end{array}$ \\
\hline
\end{tabular}




\begin{tabular}{|c|c|c|c|c|c|}
\hline & & & $\begin{array}{l}\text { - Supervisory, no } \\
\text { RX. }\end{array}$ & & $\begin{array}{l}\text { moving to a different } \\
\text { state for work. }\end{array}$ \\
\hline $\begin{array}{l}\text { McMichael, Safriet, } \\
\text { and Buerhaus (2018) }\end{array}$ & & & $\begin{array}{l}\text { Mutually exclusive } \\
\text { categories: } \\
\text { - FPA } \\
\text { - Physician } \\
\text { supervision } \\
\text { required only for } \\
\text { RX } \\
\text { - Complete } \\
\text { supervision }\end{array}$ & $\begin{array}{l}\text { State statutes, } \\
\text { regulations, and court } \\
\text { cases, 1999-2012 }\end{array}$ & $\begin{array}{l}\text { Independent in PA and } \\
\text { RX associated with } \\
\text { reduced physician } \\
\text { malpractice liability }\end{array}$ \\
\hline McMichael (2018) & Independent & CS allowed & $\begin{array}{l}\text { Mutually exclusive } \\
\text { categories: } \\
\text { - FPA } \\
\text { - Physician } \\
\text { supervision } \\
\text { required only for } \\
\text { RX } \\
\text { - Complete } \\
\quad \text { supervision } \\
\end{array}$ & $\begin{array}{l}\text { State statutes, } \\
\text { regulations, and court } \\
\text { cases, 2001-2003; } \\
2010-2015\end{array}$ & $\begin{array}{l}\text { Independent in PA and } \\
\text { RX associated with } \\
\text { increased supply of } \\
\text { NPs }\end{array}$ \\
\hline $\begin{array}{l}\text { McMichael, Spetz, and } \\
\text { Buerhaus (2019) }\end{array}$ & & & FPA & $\begin{array}{l}\text { State statutes, } \\
\text { regulations, and court } \\
\text { cases, 2006-2015 }\end{array}$ & $\begin{array}{l}\text { Independent in PA } \\
\text { associated with } \\
\text { smaller increase in } \\
\text { emergency department } \\
\text { use following } \\
\text { Medicaid expansion }\end{array}$ \\
\hline McMichael (2020a) & & & FPA & $\begin{array}{l}\text { State statutes, } \\
\text { regulations, and court } \\
\text { cases, 1998-2015 }\end{array}$ & $\begin{array}{l}\text { FPA and malpractice } \\
\text { liability interact to } \\
\text { affect C-sections and } \\
\text { inductions }\end{array}$ \\
\hline McMichael (2020b) & & & FPA & $\begin{array}{l}\text { State statutes, } \\
\text { regulations, and court } \\
\text { cases, 2011-2018 }\end{array}$ & $\begin{array}{l}\text { FPA associated with } \\
\text { decrease in opioid } \\
\text { prescriptions }\end{array}$ \\
\hline
\end{tabular}




\begin{tabular}{|c|c|c|c|c|}
\hline Muench et al. (2020) & & FPA & $\begin{array}{l}\text { NPALU, state nursing } \\
\text { boards, state statutes } \\
2008-2012\end{array}$ & $\begin{array}{l}\text { FPA associated with a } \\
\text { small increase in } \\
\text { medication adherence. }\end{array}$ \\
\hline Park et al. (2020) & & $\begin{array}{l}\text { Mutually exclusive } \\
\text { categories: } \\
\text { - Full practice and } \\
\text { prescription } \\
\text { - Full practice only } \\
\text { - Restricted practice } \\
\text { and prescription }\end{array}$ & $\begin{array}{l}\text { State statutes and } \\
\text { regulations, 2009-2015 }\end{array}$ & $\begin{array}{l}\text { Effects on visits to } \\
\text { community health } \\
\text { centers vary based on } \\
\text { type of staff visit and } \\
\text { levels of support staff. }\end{array}$ \\
\hline Perry (2012) & $\begin{array}{l}\mathrm{CS} \text { allowed }(\mathrm{Y} / \mathrm{N}) \text {, } \\
\text { regardless of oversight } \\
\text { requirements }\end{array}$ & & NPALU, 1991-2003 & $\begin{array}{l}\text { NPs less likely to } \\
\text { move from a state with } \\
\text { CS authority }\end{array}$ \\
\hline $\begin{array}{l}\text { Shishir and Plemmons } \\
(2020)\end{array}$ & & $\begin{array}{l}\text { Mutually exclusive } \\
\text { categories: } \\
\text { - Full Practice } \\
\text { - Reduced Practice } \\
\text { - Restricted Practice }\end{array}$ & $\begin{array}{l}\text { American Association } \\
\text { of Nurse Practitioners, } \\
2014-2017\end{array}$ & $\begin{array}{l}\text { NPs less likely to } \\
\text { move from a state with } \\
\text { FPA }\end{array}$ \\
\hline Smith (2022) & & FPA & $\begin{array}{l}\text { NPALU, state nursing } \\
\text { boards, state statutes, } \\
2011-2017\end{array}$ & $\begin{array}{l}\text { FPA associated with } \\
\text { increase in } \\
\text { independently billed } \\
\text { NP provided visits. } \\
\text { FPA not associated } \\
\text { with: NP visits with no } \\
\text { physician on-site; NP } \\
\text { prescription of } \\
\text { schedule II drugs; } \\
\text { work relative value } \\
\text { units provided by NPs; } \\
\text { number of chronic } \\
\text { conditions among } \\
\text { NP's patients; }\end{array}$ \\
\hline
\end{tabular}




\begin{tabular}{|c|c|c|c|c|}
\hline & & & & $\begin{array}{l}\text { inappropriate } \\
\text { prescribed antibiotics; } \\
\text { unnecessary imaging } \\
\text { ordered. }\end{array}$ \\
\hline Spetz et al. (2013) & & $\begin{array}{l}\text { Independent in PA } \\
\text { Independent in RX } \\
\text { and PA }\end{array}$ & NPALU, 2004-2007 & $\begin{array}{l}\text { Independent in PA } \\
\text { only associated with } \\
\text { fewer RX payments } \\
\text { and RX filled in retail } \\
\text { clinics. } \\
\text { Independent in PA and } \\
\text { RX associated with } \\
\text { higher RX payments } \\
\text { and more RX filled in } \\
\text { retail clinics. }\end{array}$ \\
\hline Stange (2014) & $\begin{array}{l}\text { CS allowed }(\mathrm{Y} / \mathrm{N}), \\
\text { regardless of oversight } \\
\text { requirements }\end{array}$ & & NPALU, 1996-2008 & $\begin{array}{l}\text { CS RX allowed is } \\
\text { associated with more } \\
\text { office visits. No } \\
\text { effects on usual source } \\
\text { of care and amount } \\
\text { paid. }\end{array}$ \\
\hline Timmons (2017) & $\begin{array}{l}\text { Mutually exclusive } \\
\text { categories: } \\
\text { - CS without } \\
\text { supervision } \\
\text { - CS with supervision } \\
\text { - No CS }\end{array}$ & & NPALU, 1999-2012 & $\begin{array}{l}\text { No effects on claims, } \\
\text { care days, RX claims }\end{array}$ \\
\hline $\begin{array}{l}\text { Traczynski and } \\
\text { Udalova (2018) }\end{array}$ & & FPA & $\begin{array}{l}\text { NPALU, state statues, } \\
\text { BON rules and } \\
\text { regulations, 1995-2012 }\end{array}$ & $\begin{array}{l}\text { FPA associated with: } \\
\text { decreased emergency } \\
\text { room visit; increased } \\
\text { appointment } \\
\text { availability; increases }\end{array}$ \\
\hline
\end{tabular}




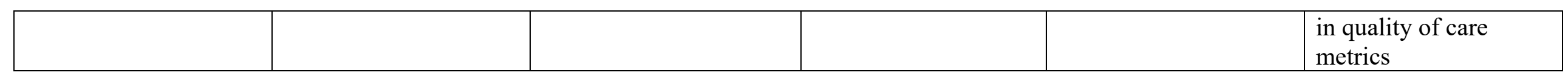

Notes: Additional abbreviations used in this table: AANP - "American Association of Nurse Practitioners"; CS -"Controlled Substance"; FPA - "Full Practice Authority"; NPALU - "Nurse Practitioner Annual Legislative Update"

SOP - "scope of practice." 